\title{
Studies on changes in quality characteristics of Indian horse chestnut (Aesculus indica Colebr.) flour during storage
}

\author{
Pradeep Kumar ${ }^{1 *}$ and N. S. Thakur ${ }^{2}$ \\ Forestry, Nauni, Solan- 173230 (Himachal Pradesh), INDIA \\ *Corresponding author. E-mail: pradeep6751@gmail.com \\ Received: May 31, 2016; Revised received: October 15, 2016; Accepted: February 13, 2017
}

Department of Food Science and Technology (FST), Dr Yashwant Singh Parmar University of Horticulture and

\begin{abstract}
Indian horse chestnut (Aesculus indica Colebr.) is a rich source of starch but contains toxic compound known as saponins which makes it bitter and unsuitable for edible purposes. To exploit the starch source for edible purpose first of all the saponins were removed to a acceptable limit by pretreating the crushed mass of Indian horse chestnut as suggested earlier. Edible mass of Indian horse chestnut was dried and milled into flour and packed in different packaging materials and further stored under refrigerated $\left(4-7^{\circ} \mathrm{C}\right)$ and ambient $\left(18-25^{\circ} \mathrm{C}\right)$ storage conditions for 6 months. The flour packed in aluminium laminated pouches and stored under refrigerated condition showed minimum increase in physico-chemical and rheological characteristics like moisture content (6.49\%), water activity $(0.155)$, reducing sugars $(1.72 \%)$ and retained highest amounts of total solids $(93.50 \%)$, total sugars $(3.75 \%)$, starch $(63.89 \%)$, ash $(2.36 \%)$, proteins $(102.23 \mathrm{mg} / 100 \mathrm{~g})$ along with oil absorption capacity $(1.54 \mathrm{ml} / \mathrm{g})$, water absorption capacity $(4.44 \mathrm{ml} / \mathrm{g})$ and bulk density $(0.635 \mathrm{~g} / \mathrm{ml})$. The sensory characteristics scores like colour (7.60), taste (7.25), aroma (6.88), texture (6.87) and overall acceptability (7.08) were retained highest in this packaging material as compared to others.
\end{abstract}

Keywords: Aluminium laminated pouch, Indian horse chestnut flour, Oil absorption capacity, Saponins, Starch

\section{INTRODUCTION}

There are 17 species of Aesculus genus widely distributed throughout the temperate regions of the world like Asia, Europe and North America. Among these Aesculus indica Colebr. known as Indian horse chestnut, is widely distributed at an elevation between 2,000 and 3,000 metres (Parmar and Kaushal, 1982) in the moist, shady ravines of Kashmir, Himachal Pradesh and Uttrakhand in India. In HP, the trees of this species are found in the forests of various districts including Solan, Shimla, Sirmour, Kullu, Kangra, Mandi and Chamba etc. Starch, as organic matter, has the highest incidence in the seed (Cukanovic et al., 2011). The nut however contains anti-nutritional factor like saponins (aesculin) which make it inedible and poisonous. Beside saponins, other compounds like nicotine, quercitin, quercitrin, rutin and shikimic acid are also found in this nut. Some animals like deer and squirrels remain unaffected after consumption of its nuts. The crushed nuts if fed to cattle are reported to improve the quality and quantity of milk. Tattwakhar, a type of halwa (an Indian confectionary) is made and used as phalahar (non-cereal food) during fasts in certain parts of HP after removal of saponins by traditional approaches (Rajasekaran and Joginder, 2009). Therefore, the present investigation were aimed to study the physico-chemical characteristics changes in the pretreated horse chestnut flour during storage.

\section{MATERIALS AND METHODS}

Indian horse chestnuts (Aesculus indica Colebr.) harvested at optimum maturity were procured from chota Bhangal area of district Kangra (HP) and then nuts were dehulled manually and grated with the help of mechanical grater and the grated mass was treated by the following treatments and further drying of pre-treated mass was done as suggested earlier. The best dried mass was ground into flour in a grinding mill. A sample of $500 \mathrm{~g}$ lot each was packed in four different packaging material viz. aluminium laminated pouch $\mathrm{T}_{1}(99.8 \mathrm{gsm})$, polyethylene pouch $\mathrm{T}_{2}$ (93.9 gsm), Glass jar $\mathrm{T}_{3}$ and HDPE jar $\mathrm{T}_{4}$. The packed flour was stored in ambient temperature $\left(18-25^{\circ} \mathrm{C}\right)$ and refrigerated temperature $\left(4^{\circ} \mathrm{C}-7^{\circ} \mathrm{C}\right)$ upto a period of 6 months for storage studies. The observations for different quality parameters were recorded at 0,3 and 6 months interval of storage.

Physico-chemical, rheological and sensory analysis: Among the different chemical characteristics of flour moisture content was estimated by drying the weighed samples to a constant weight in a hot air oven at $70 \pm 1^{\circ}$ C. Loss in weight of flour after drying representing the moisture content and was expressed as per cent (W/ 
W), whereas, total solids were estimated by subtracting moisture content from the weight of the flour. Water activity of the flour was estimated by computer digital water activity meter $\left(\mathrm{HW}_{3}\right.$ model, Rotronic International, Switzerland). Starch content of the flour was determined by the method given by Ranganna (2009). Sugars were estimated as per the standard procedure given by Lane and Eynon (1923). Protein in the flour was determined by Lowry's method as described by Sadassivam and Manickam (1991). Ash content was determined by using muffle furnace at temperature of $550^{\circ} \mathrm{C}$ as given by Ranganna (2009). The quantitative estimation of saponins content in flour was carried out as per the standard procedure given by Obadoni and Ochuko (2001). Bulk density of Indian horse chestnut flour was determined by the procedure of Okaka and Potter (1979). Water absorption capacity of flour was determined by procedure given by Beuchart, (1977). Oil absorption capacity of flour was determined as given by Beuchart, (1977). Sensory analysis of flour was carried out by using 9 point hedonic scale as described by the Amerine et al. (1965).

Statistical analysis: The data pertaining to sensory evaluation of Indian horse chestnut flour were analyzed by Randomized Block Design (RBD). Whereas the data pertaining to the physico - chemical and reheological of the flour were analysed using Completely Randomized Design (CRD) (Cochran and Cox, 1967).

\section{RESULTS}

Results in Fig. 1 (a, c and d) indicates that there was a general increase in moisture, water activity and reducing sugars was recorded during 6 months storage of flour of horse chestnut. Data presented in Fig.. 1 (b, e, f, g, $\mathrm{h}, \mathrm{i}, \mathrm{j}, \mathrm{k}, \mathrm{l}, \mathrm{m}, \mathrm{n}, \mathrm{o}, \mathrm{p}$ and $\mathrm{q}$ ) reveals that total solids, total sugars, starch, ash, proteins, oil absorption capacity, water absorption capacity, bulk density, saponins, colour, taste, aroma, texture and overall acceptability decreased with the advancement of storage period. The moisture content, water activity and reducing sugars of flour increased significantly from 6.30 to 7.49 per cent, 0.147 to 0.191 per cent and 1.70 to 1.77 per cent respectively during storage. All means scores differ significantly $(\mathrm{p} \leq 0.05)$. However, the total solids and total sugars of flour of horse chestnut decreased significantly from 93.68 to 92.50 per cent and 3.87 to 3.56 per cent during storage. Starch of flour of horse chestnut shows that it decreased from 64.20 to 63.52 per cent. A significant decrease in ash content and total protein of flour was also recorded from 2.42 to 2.26 per cent and 105.00 to $97.26 \mathrm{mg} / 100 \mathrm{~g}$. Oil absorption capacity, water absorption capacity, saponins and bulk density of flour decreased significantly from 1.66 to $1.39 \mathrm{ml} / \mathrm{g}, 4.70$ to $4.20 \mathrm{ml} / \mathrm{g}$, 2.10 to 2.02 per cent and 0.670 to $0.571 \mathrm{~g} / \mathrm{ml}$. While comparing different packaging material, maximum TS, total sugars, total proteins and starch were recorded in
ALP $T_{1}$, however, the minimum were recorded in $T_{2}$ during storage of 6 months. Among the different packaging material, minimum water activity, moisture and reducing sugars of flour were recorded in ALP $\mathrm{T}_{1}$ followed by $\mathrm{T}_{3}$ and $\mathrm{T}_{4}$ during storage. Results pertaining to changes in sensory scores (colour, taste, aroma, texture \& overall acceptability) of flour during storage are presented in Figure $1(\mathrm{~m}, \mathrm{n}, \mathrm{o}, \mathrm{p}, \mathrm{q})$. The colour, taste, aroma, texture and overall acceptability scores of flour decreased during storage of six months. Further, when the different packaging treatments were compared, maximum scores for sensory attributes was observed in the flour packed in ALP $\left(\mathrm{T}_{1}\right)$ and minimum in PEP $\left(\mathrm{T}_{2}\right)$ during storage.

\section{DISCUSSION}

The above results are in confirmatory with Misra and Kulshrestha (2003) which observed increase in moisture content (8.08-9.67\%) after 6 months of storage under ambient and (8.08-8.68\%) under refrigerated conditions in potato flour and Foda et al. (1970) which observed increase in reducing sugars in orange powder.The results on above physico-chemical characteristics of horse chestnut flour shows general increase of water activity, moisture and reducing sugar in the flour observed during storage of 6 months might be due to the hygroscopic nature of the dried product. Flour packed in aluminium laminated pouch (ALP) recorded significantly minimum increase of above physico-chemical characteristics during storage as compared to other packaging material where these were more. This might be due to the air which remained trapped inside the pouch at the time of manual sealing or it may be because of the minute permeable nature (as a result of pin holes in the aluminium foil) of ALP which might have given the way for the slight movement of moisture and air inside the pouch. Whereas, higher increase in these quality characteristics in polyethylene pouch might be due to their higher permeability to air and moisture. General decrease in total solids, total sugars, starch, ash, proteins, oil absorption capacity, Water absorption capacity, bulk density, saponins and sensory attributes was observed during storage of flour might be due to the increase in the moisture and air uptake, exposure of flour to light, utilization of sugars in non-enzymatic browning reactions, loss of total protein during storage might be due to their denaturation because of increase in moisture content and their involvement in maillards reactions to form brown pigment (Burton, 1945). Similar trend of results for $\mathrm{pH}$ and total sugars have been observed by Foda et al. (1970) in orange powder. Misra and Kulshrestha (2003) for decrease in starch content of potato flour (78.05-77.17\%) after 6 months storage under ambient and (78.05-77.33\%) under refrigerated conditions. Akhtar et al. (2005) for decrease in ash content and oil content of whole wheat 
Pradeep Kumar and N. S. Thakur / J. Appl. \& Nat. Sci. 9 (1): 445 - 450 (2017)
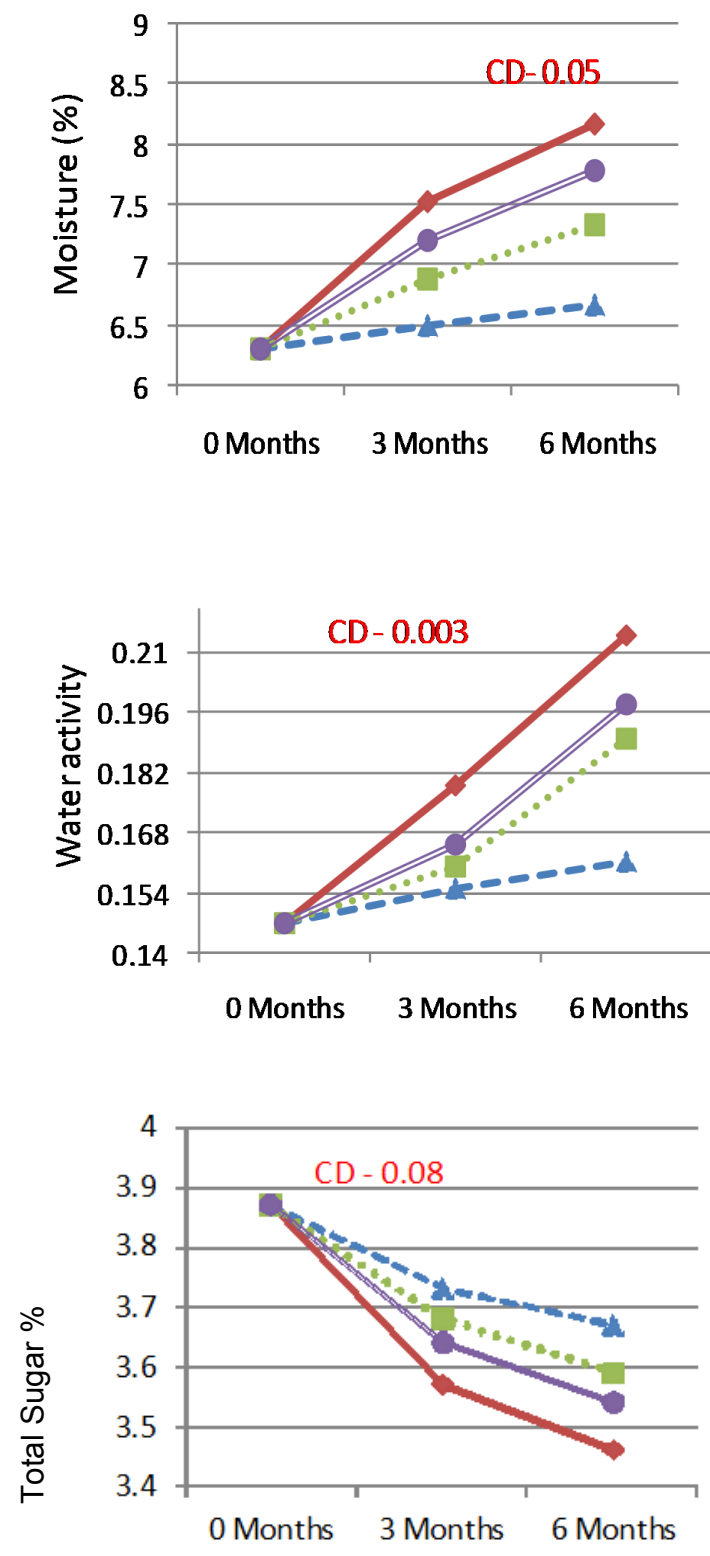

e

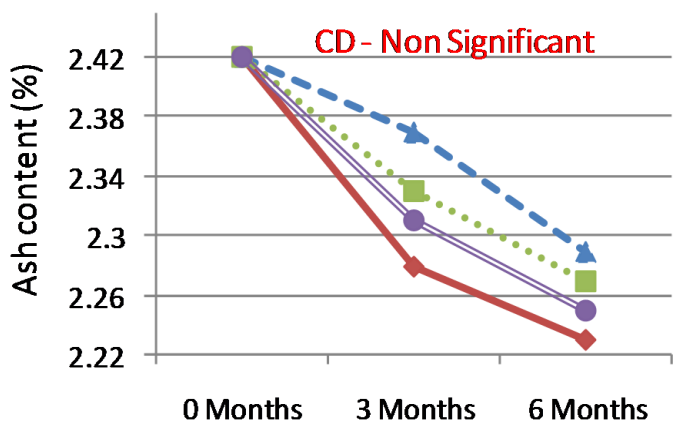

g
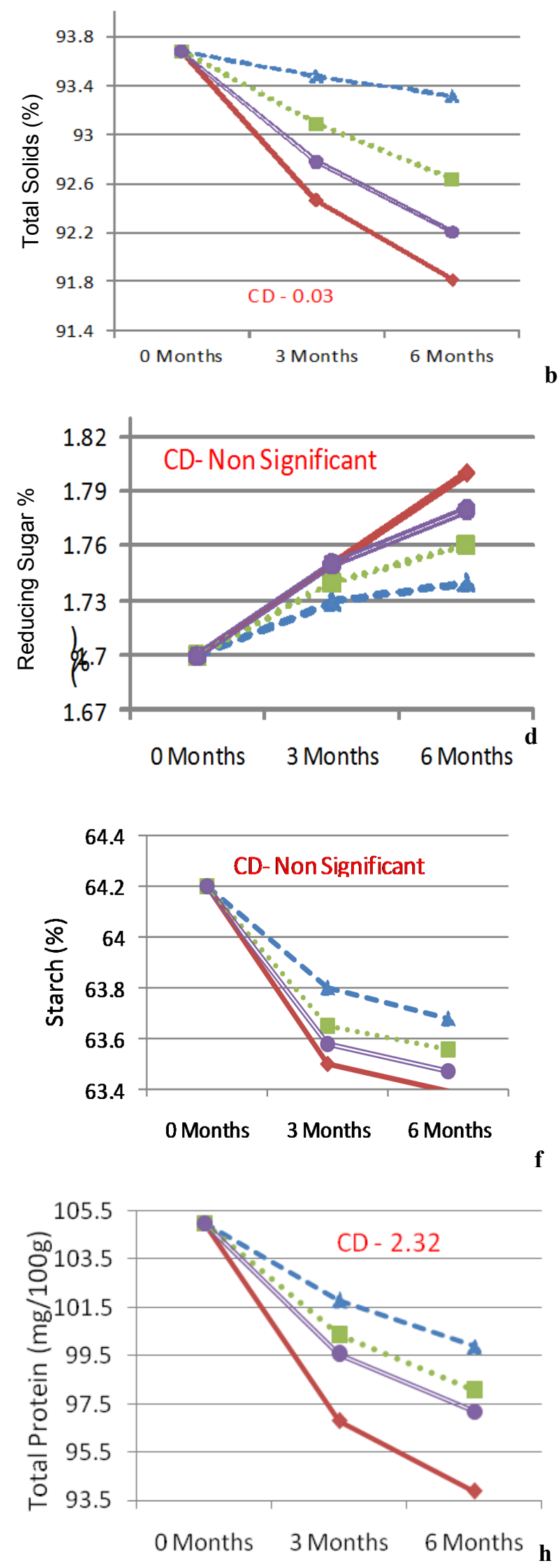

Contd......... 
Pradeep Kumar and N. S. Thakur / J. Appl. \& Nat. Sci. 9 (1): 445 - 450 (2017)
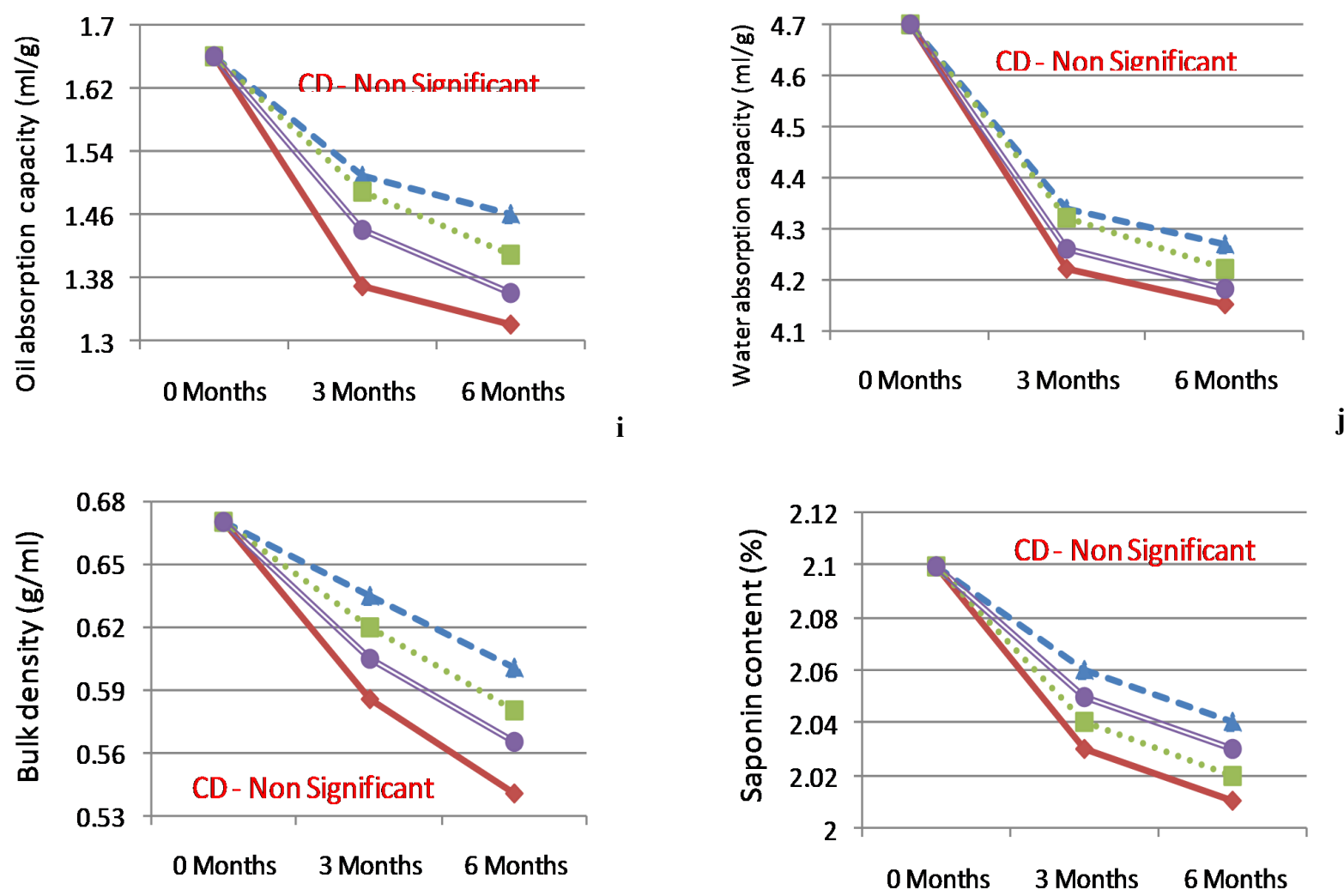

k
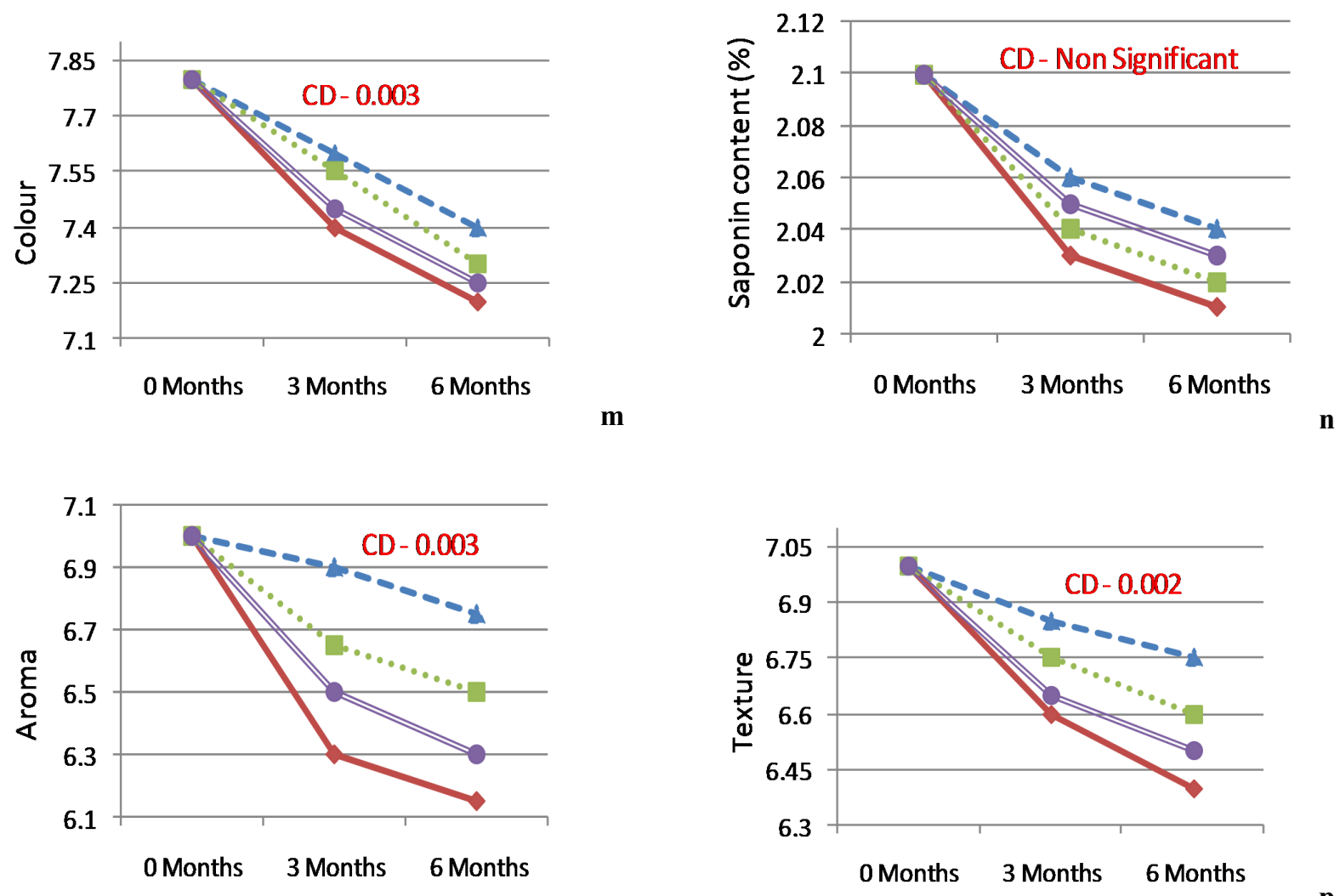

o Contd........ 


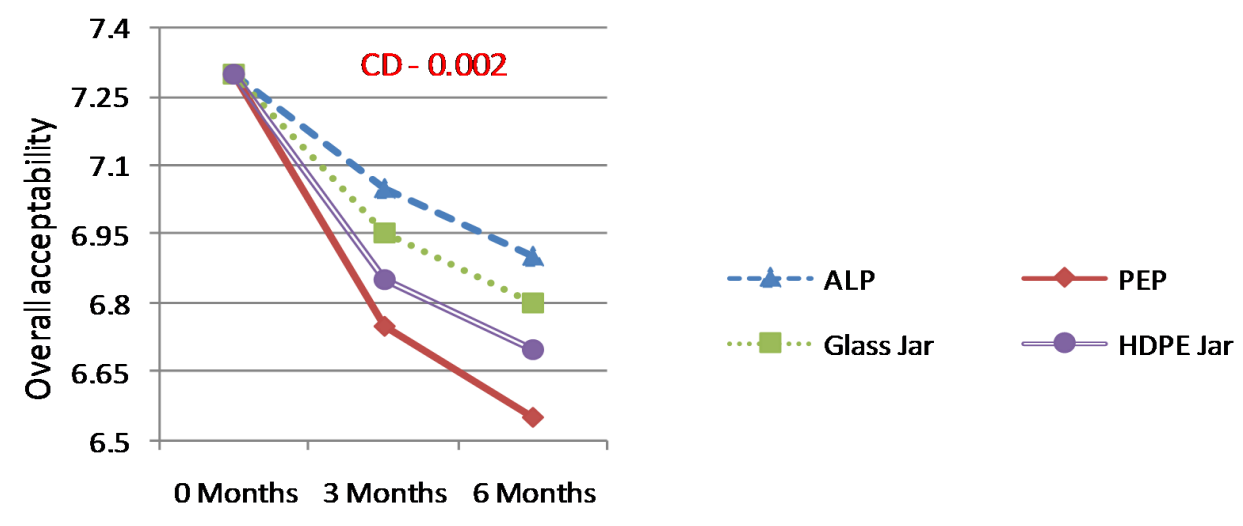

Fig 1. (a to q): Effect of different packaging material and storage intervals on the physico-chemical and sensory quality attributes of horse chestnut flour.

flour stored for 60 days under ambient conditions. Similar results for oil absorption capacity have been reported by Akusu and Kinn (2013) in ogbono flour from $0.67-0.42 \mathrm{~g} / \mathrm{g}$ after 4 weeks of storage. Present results are in conformity with those of Aboubakar et al. (2010) in taro flour for water absorption capacity. Decrease in sensory characteristics scores of flour during storage might be due to the changes in various physico-chemical characteristics during storage which lead the judges to award the lower scores to the flour with respect to the various sensory attributes. Similar trend for sensory characteristics have been observed by Sagar and Khurdiya (1999) in dehydrated ripe mango slices.

It is evident that decrease in these physico-chemical and sensory characteristics was significantly much less in ALP compared to polyethylene pouch, glass jar and HDPE jar. This might be due to the opaqueness of aluminium foil in the ALP to light and minute permeability of the packaging material to oxygen and water vapour that prevented photo-oxidation and oxidation reactions. That is why, horse chestnut flour retained better quality as compared to the other packages.

\section{Conclusion}

The moisture content, water activity and reducing sugars of flour increased significantly from 6.30 to 7.49 per cent, 0.147 to 0.191 per cent and 1.70 to 1.77 per cent respectively during storage. However, the total solids, total sugars, starch, ash content, total protein, oil absorption capacity, water absorption capacity, saponins and bulk density of flour of horse chestnut decreased significantly from 93.68 to 92.50 per cent, 3.87 to 3.56 per cent, 64.20 to 63.52 per cent, 2.42 to 2.26 per cent, 105.00 to $97.26 \mathrm{mg} / 100 \mathrm{~g}, 1.66$ to 1.39 $\mathrm{ml} / \mathrm{g}, 4.70$ to $4.20 \mathrm{ml} / \mathrm{g}, 2.10$ to 2.02 per cent and 0.670 to $0.571 \mathrm{~g} / \mathrm{ml}$. Among different packaging treatments aluminium laminated pouch was found to be the best as compared to others on the basis of better retention of various physico-chemical characteristics viz. TS, total proteins and starch etc and sensory characteristics viz. colour, texture, taste and overall acceptability of flour. So it can be concluded from the above studies that Indian horse chestnut flour packed in aluminium laminated pouch $(99.8 \mathrm{gsm})$ can be stored under refrigerated condition successfully for 6 months without much changes in its quality as compared to ambient conditions. So, this flour can further be used for the development of various edible products in future.

\section{ACKNOWLEDGEMENTS}

Authors convey heartfelt thanks to the department of Food Science and Technology, UHF, Nauni, Solan for co-operation and providing the facilities to carry out this research. Authors are also grateful to farmers of chota bhangal Kangra district (HP) for providing horse chestnut fruits as a main raw material for present research.

\section{REFERENCES}

Aboubakar, Njintang, Y.N. Nguimbou, R.M. Scher, J. and Mbofung, C.M. 2010. Effect of storage on the physicochemical, functional and rheological properties of taro (Colocasia esculenta) flour and paste. Innovative Romanian Food Biotechnology, 7:123-128.

Akhtar, S. Anjum, F.M. and Rehman, S.U. 2005. Effect of iron and zinc fortification on chemical composition of whole wheat flour. Journal of Research (Science), Bahauddin Zakariya University, Multan, Pakistan, 16 (2): $95-103$

Akusu, O.M and Kiin, D.B. 2013. Effect of storage period on selected functional, chemical stability and sensory properties of bush mango (irvingia Gabonensis) seed flour. Africa Journal of Food Science and Technology, 4(6):136-140.

Amerine, M.A. Pangborn, R.M.and Roessler, E.B. (1965). Principles of sensory evaluation of food. Academic Press, London, pp 236-268. 
Beuchart, L.R. (1977). Functional and Electrophoretic Characteristics of Succinylated Peanut Flour Protein. Journal Agriculture Food Chemistry, 25: 258-261.

Burton, W.G. (1945). The storage life of a sample of potato flour produced from potato slices dried in a sugar beet factory. Journal Social Chemistry Industries, 64: 8586.

Cochran, W.G. and Cox, C.M. (1967). Experimental Design, John Wiley and Sons, New York, pp 171-217.

Cukanovic, J. Todorovic, J.N. Ognjanov, V. Mladenovic, E. Ljubojevic, M. and Kurjakov, A. 2011. Biochemical composition of the horse chestnut seed (aesculus hippocastanum L.). Arch. Biol. Sci., Belgrade, 63 (2):345351. Foda, Y.H. Hamed, M.G.E. and Abd-Allah, M.A. 1970. Preservation of orange and guava juice by freeze drying. Food Technology, 24: 1392-1398.

Lane, J.H. and Eynon, L. (1923). Determination of reducing sugar by Fehling's solutions with methylene blue as indicator. J. Soc. Chem. Ind. 42: 32.

Misra A and Kulshrestha K. (2003). Effect of storage on nutritional value of potato flour made from three potato varieties. Plant Foods for Human Nutrition, 58: 1-10.

Obadoni, B.O. and Ochuko, P.O. (2001). Phytochemical studies and comparative efficacy of the crude extracts of some Homostatic plants in Edo and Delta States of Nigeria. Global Journal Pure Applied Science, 8: 203-208.

Okaka, J.C. and Potter, N.N. (1979). Physicochemical and functional properties of cowpea powders processed to reduce beany flavour. Journal of Food Science, 44: $1235-1240$

Parmar, C. and Kaushal, M.K. (1982). Aesculus indica. In:Wild Fruits. Kalyani Publishers, New Delhi, India, pp. 6-9.

Rajasekaran, A. and Joginder, S. (2009). Ethnobotany of Indian horse chestnut (Aesculus indica) in Mandi district, HP. Indian Journal of Traditional Knowledge, 8(2): $285-286$

Ranganna, S. (2009). Handbook of analysis and quality control for fruit and vegetable products. Tata McGraw Hill, New Delhi. p1112.

Sadassivam, S. and Manickam, A. (1991). Biochemical methods. New Age International Limited Publishers, New Delhi. pp 56.

Sagar, V.R. Khurdiya, D.S. and Balakrishanan, K.A. (1999). Quality of dehydrated ripe mango slices as affected by packaging material and mode of packaging. Journal of Food Science and Technology, 36(1): 67-70. 